\title{
Article \\ Bead-Immobilized Multimodal Molecular Beacon-Equipped DNA Machinery for Specific RNA Target Detection: A Prototypical Molecular Nanobiosensor
}

\author{
Jeonghun Kim ${ }^{1,+}$, So Yeon Ahn ${ }^{1,+}$ and Soong Ho Um ${ }^{1,2, *(\mathbb{D}}$ \\ 1 School of Chemical Engineering, Sungkyunkwan University, Suwon 16419, Gyeonggi-do, Korea; \\ realread2@naver.com (J.K.); melissa100@naver.com (S.Y.A.) \\ 2 SKKU Advanced Institute of Nanotechnology (SAINT), Sungkyunkwan University, \\ Suwon 16419, Gyeonggi-do, Korea \\ * Correspondence: sh.um@skku.edu \\ $+\quad$ These authors equally contributed to this work.
}

check for

updates

Citation: Kim, J.; Ahn, S.Y.; Um, S.H. Bead-Immobilized Multimodal Molecular Beacon-Equipped DNA Machinery for Specific RNA Target Detection: A Prototypical Molecular Nanobiosensor. Nanomaterials 2021, 11, 1617. https://doi.org/10.3390/ nano11061617

Academic Editors: Anton Valeri Liopo and Paul J. Derry

Received: 29 April 2021

Accepted: 18 June 2021

Published: 20 June 2021

Publisher's Note: MDPI stays neutral with regard to jurisdictional claims in published maps and institutional affiliations.

Copyright: (c) 2021 by the authors. Licensee MDPI, Basel, Switzerland. This article is an open access article distributed under the terms and conditions of the Creative Commons Attribution (CC BY) license (https:/ / creativecommons.org/licenses/by/ $4.0 /)$.

\begin{abstract}
A variety of nanostructured diagnostic tools have been developed for the precise detection of known genetic variants. Molecular beacon systems are very promising tools due to their specific selectivity coupled with relatively lower cost and time requirements than existing molecular detection tools such as next generation sequencing or real-time PCR (polymerase chain reaction). However, they are prone to errors induced by secondary structure responses to environmental fluctuations, such as temperature and $\mathrm{pH}$. Herein, we report a temperature-insensitive, bead-immobilized, molecular beacon-equipped novel DNA nanostructure for detection of cancer miRNA variants with the consideration of thermodynamics. This system consists of three parts: a molecular beacon for cancerspecific RNA capture, a stem body as a core template, and a single bead for solid-support. This DNA system was selectively bound to nanosized beads using avidin-biotin chemistry. Synthetic DNA nanostructures, designed based on the principle of fluorescence-resonance enhanced transfer, were effectively applied for in vitro cancer-specific RNA detection. Several parameters were optimized for higher performance, with a focus on thermodynamic stability. Theoretical issues regarding the secondary structure of a single molecular beacon and its combinatory forms were also studied. This study provides design guidelines for new sensing systems of miRNA variation for next-generation biotechnological applications.
\end{abstract}

Keywords: molecular beacon; DNA nanostructure; miRNA; sensor

\section{Introduction}

Genomics has guided the identification of numerous genetic variants associated with cancers [1,2]. This has spurred the development of genetic analytic tool kits with high sensitivity and selectivity for detecting such variants. A number of applications have recently been developed in relation to these genetic analytical tools. Some of them show breakthrough detection ability. Most of these applications are focused on increasing the sensitivity itself, such as amplifying the target or amplifying the signal [3-7]. In particular, molecular beacons, consisting of DNA hairpins with a fluorescent label at one end and quenchers at the other end, are widely used because they obviate the requirement to label the target molecule. Molecular beacon technology is a groundbreaking technology that easily detect target biomarkers by simple mechanism. However, hairpin structure without rigid support is less stable and it makes high background signal. Therefore, it is commonly used that immobilize hairpin structure onto solid substrates [8]. Although surface-immobilized molecular beacons have been mainly reported [9], most studies have simply described a one-to-one correspondence to the read-out of targets. The critical challenge faced by immobilized molecular beacons is precisely controlling the density and 
orientation of grafted DNA probes to minimize the interactions between probes and to maximize the target accessibility [10]. Herein, we demonstrate a new surface-immobilized molecular beacon sensor employing a robust DNA nanostructure that enables precise signal adjustment and probe representation. The DNA nanostructure-integrated molecular beacon system is able to capture a target miRNA marker and simultaneously provide quantitative indication of probe internalization that can function as a part of a targetlabel-free optical genetic biosensor. The optimized DNA nanostructure contributed to development of an advanced molecular beacon sensor enabling quantitative detection of breast-cancer specific RNA markers.

\section{Materials and Methods}

All nucleic acids, including DNAs $\left(Y_{1}\right.$, biotin-labeled $Y_{1}$, FAM-labeled $\left.Y_{2}, Y_{3}, Y_{L}\right)$, mismatched DNAs, and RNAs (EZH2, miRNA 21) were purchased from Integrated DNA Technologies (Coralville, IA, USA). $Y_{L}$ modified with both dark quencher (Iowa black RQ) at the $5^{\prime}$ end and cyanine dyes (Cy5) at an intra-molecular location was purchased from Integrated DNA Technologies. Agar powder was purchased from Sigma-Aldrich (St. Louis, MO, USA). Chemicals used in this experiment, which included ethidium bromide, a $25 \mathrm{bp}$ DNA stepladder, 50 bp DNA ladder, and $6 \times$ blue/orange loading dye, were purchased from Promega (Fitchburg, WI, USA). TAE buffer $(50 \times)$ and TBE buffer $(10 \times)$ were purchased from Noble Biosciences (Suwon, Gyeonggi-do, Korea). SYBR gold nucleic acid gel stain $(10,000 \times)$ and ultrapure Dnase/Rnase-free water were purchased from Thermo Fisher Scientific (Waltham, MA, USA). Streptavidin-coated polystyrene beads (110 $\mathrm{nm}$-sized) were purchased from Bangs Laboratories (Fishers, IN, USA).

\subsection{Design and Evaluation of DNA Sequences Using Web-Based Analysis Programs}

The thermodynamic energies of all oligonucleotides used in this experiment were investigated via OligoAnalyzer 3.1 provided by Integrated DNA Technologies. In addition, thermodynamic energies of hairpin-looped structures of oligo candidates were investigated using Beacon Designer web-based software provided by Premier Biosoft International. Sequences and other factors, such as temperatures and salt concentrations, were entered into the software. Here, we designed several sequences as follows. Each sequence is also described in Figure S3.

Y-DNA, y shaped DNA structure which composed by $\mathrm{Y}_{1}, \mathrm{Y}_{2}, \mathrm{Y}_{3}$

L-DNA, y shaped DNA structure with loop region which composed by $\mathrm{Y}_{1}, \mathrm{Y}_{2}, \mathrm{Y}_{\mathrm{L}(\mathrm{loop})}$

\subsection{Synthesis of $L-D N A$}

Lyophilized oligonucleotides were separately redissolved in TE buffer (10 mM Tris$\mathrm{HCl}(\mathrm{pH}$ 8.0) and $0.1 \mathrm{mM}$ EDTA). The optical density (OD) of each oligo solution was measured by a UV-Vis photometer (BioPhotometer, Eppendorf, Hamburg, Germany), which indicated the concentration in $\mu \mathrm{g} / \mu \mathrm{L}$. Each solution was stored at $4{ }^{\circ} \mathrm{C}$. To prepare $6 \mu \mathrm{M}$ Y- and L-DNA solutions, each oligonucleotide was mixed in a buffer composed of $50 \mathrm{mM} \mathrm{NaCl}, 10 \mathrm{mM}$ Tris- $\mathrm{HCl}$ (pH 8.0), and $0.1 \mathrm{mM}$ EDTA. The mixture was put into a thermal cycler (Mastercycler Pro, Eppendorf) and annealed with temperature- and timevarying processes. Samples were then heated to $95^{\circ} \mathrm{C}$ for $2 \mathrm{~h}$, followed by cooling to $65^{\circ} \mathrm{C}$ for $5 \mathrm{~min}$ and further cooling to $60^{\circ} \mathrm{C}$ for $5 \mathrm{~min}$. The temperature was then reduced by $1{ }^{\circ} \mathrm{C}$ per minute until it reached $20^{\circ} \mathrm{C}$. Samples were stored at $4{ }^{\circ} \mathrm{C}$ until use.

\subsection{Prediction of Possible Secondary Structures of L-DNA through Web-Based Software}

Thermodynamic properties and secondary structures of each oligonucleotide were obtained using the free Mfold program. The gateway for the Mfold web server is http://unafold.rna.albany.edu/, accessed on 2 September 2008. Predicted secondary structures in one- and two-dimensions were obtained under the following conditions: $6 \mu \mathrm{M}$ oligos, $50 \mathrm{mM} \mathrm{NaCl}$, and $37^{\circ} \mathrm{C}$ or $50^{\circ} \mathrm{C}$. 1-D data were further used to construct a three-dimensional model using RNA composer (http://rnacomposer.cs.put.poznan.pl/, 
accessed on 26 April 2012). The RNA composer output was saved in pdb format, and collected images were produced using PyMOL software (http:/ / www.pymol.org, accessed on 1 August 2006).

\subsection{Melting Curves of Oligonucleotide Sequences}

The thermal denaturation of oligos was measured by the 7500 Real Time PCR System manufactured by Applied Biosystems (Foster City, CA, USA) and analyzed using 7500 software V2.3. SYBR Green I from Molecular Probes (Eugene, OR, USA) was used as a nucleic acid staining agent. SYBR Green I solution, which was diluted 20,000-fold, was added to $600 \mathrm{ng}$ of DNA solution in a final volume of $100 \mu \mathrm{L}$ on a 96-well PCR plate. Melting curves were collected in the SYBR channel using the ramp rate of $+0.5^{\circ} \mathrm{C} / \mathrm{min}$ from $30-95^{\circ} \mathrm{C}$. Fluorescence measurements were performed at each step during this ramp. Melting curves were performed at least in triplicate.

\subsection{Gel Electrophoresis and Single-Stranded Conformational Polymorphism (SSCP) Analysis}

DNA products were evaluated by $3 \%$ agarose gel electrophoresis. After DNA samples were synthesized, $0.6 \mu \mathrm{g}$ of each sample was added to $12 \mu \mathrm{L}$ of loading buffer $(2 \mu \mathrm{L}$ of $6 \times$ loading dye with DNase-free water). Gel electrophoresis was performed at $100 \mathrm{~V}$ for $40 \mathrm{~min}$, and gels were then immediately stained with ethidium bromide $(\mathrm{EtBr})(2 \mu \mathrm{g} / \mathrm{mL})$ for $20 \mathrm{~min}$. For single-stranded conformational polymorphism (SSCP) analysis, polyacrylamide gel electrophoresis was performed. Products $(0.3 \mu \mathrm{g}$ of DNA sample) were evaluated by $15 \%$ polyacrylamide gel electrophoresis. Gel electrophoresis was performed at $100 \mathrm{~V}$ for 1 or $2 \mathrm{~h}$, and then gels were immediately stained with SYBR gold for $30 \mathrm{~min}$. The fluorescent intensity of FAM under UV light was evaluated for $0.3 \mu \mathrm{g}$ L-DNA and other samples. Gel images were visualized using the GELDoc-it imaging system combined with a Launch VisionWorksLS UPV and were analyzed using a TotalLab Quant gel quantification software version 2.01, provided by ImageMaster of TotalLab Ltd. (Newcastle, UK).

\subsection{Measurement of Thermal Stability and Detection Efficiency of L-DNA and Its Derivatives}

Thermal stability at $9,16,25,37$, and $45^{\circ} \mathrm{C}$ was measured using a SpectraMax M5 (Molecular Devices, Sunnyvale, CA, USA). Thermal stability of $1.2 \mu \mathrm{M}$ of L-DNA and its derivatives was measured in a $40 \mu \mathrm{L}$ final volume on a 384-well plate. To investigate detection efficiency, $5 \mu \mathrm{L}$ of $1.2,0.6$, and $0.12 \mu \mathrm{M}$ complementary target mRNA EZH2 was added to $40 \mu \mathrm{L}$ of L-DNA and its derivatives. After incubation for $30 \mathrm{~min}$ at $37^{\circ} \mathrm{C}$ to allow binding to target molecules, fluorescence of the mixtures was measured using a SpectraMax M5. The Cy5 signal was measured at wavelengths of $648 \mathrm{~nm}$ and $675 \mathrm{~nm}$. Fluorescence measurements were obtained from triplicate experiments and sample standard deviation was calculated for statistical evaluation.

\subsection{Preparation of a Bead-Immobilized Molecular Beacon-Equipped DNA Nanobiosensor}

Free molecular-beacon-equipped DNA nanosensors, which we also refer to as L-DNA, was added to a solution of $110 \mathrm{~nm}$ PS beads to construct bead-immobilized molecular beacon-equipped DNA nanobiosensors. This PS bead solution was provided by Bangs Laboratories (Fishers, IN, USA) and diluted in PBS (0.05\% Tween 20) at a 1\% volumetric ratio. $50 \mu \mathrm{L}$ of the $6 \mu \mathrm{M}$ L-DNA solution was added to $500 \mu \mathrm{L}$ diluted bead solution at a 10:1 volumetric ratio. The mixture was then incubated for $1 \mathrm{~h}$ at room temperature. After sequential reactions, the samples were centrifuged at $10,000 \mathrm{~g}$ for $30 \mathrm{~min}$ at $4{ }^{\circ} \mathrm{C}$, followed by two washes with $500 \mu \mathrm{L}$ of PBS and resuspension in $50 \mu \mathrm{L}$ of buffer $(50 \mathrm{mM} \mathrm{NaCl}$, $10 \mathrm{mM}$ Tris- $\mathrm{HCl}$ (pH 8.0), and $0.1 \mathrm{mM}$ EDTA). $50 \mu \mathrm{L}$ of L-DNA beads were prepared. To investigate detection efficiency, $2 \mu \mathrm{M}$ of L-DNA and bead-immobilized L-DNA with 2, 0.5, $0.125,0.03125$, and $0 \mu \mathrm{M}$ of the miRNA-21 were prepared in $40 \mu \mathrm{L}$ of $50 \mathrm{mM} \mathrm{NaCl}, 10 \mathrm{mM}$ Tris- $\mathrm{HCl}$ (pH 8.0), and $0.1 \mathrm{mM}$ EDTA in a 384-well plate. Fluorescence of the mixtures was measured by a SpectraMax M5 at $20^{\circ} \mathrm{C}$. FAM and Cy5 were measured at excitation wavelengths of 495 and $648 \mathrm{~nm}$ and emission wavelengths of 525 and $675 \mathrm{~nm}$, respectively. 
Using FAM as a standard, detection efficiency was evaluated as the relative Cy5/FAM signal variation. The binding capacity of $110 \mathrm{~nm}$-sized streptavidin-coated microspheres was estimated to be approximately $3.6 \mu \mathrm{g}$ biotin-FITC $/ \mathrm{mg}$ microspheres. Considering that the molecular weight of the biotin-FITC is around $831 \mathrm{Da}$, the number of microspheres per gram was $1.391 \times 10^{15}$. This value indicates that one microsphere has approximately 1875 biotin-FITC particles attached to it.

\section{8. $\mathrm{pH}$ and Temperature Stability Measurements of Bead-Immobilized Molecular Beacon-Equipped DNA Nanobiosensors}

The stability of bead-immobilized molecular beacon-equipped DNA nanobiosensors was tested in different $\mathrm{pH}$ environments. When a loop-stem structure formed, Cy5 reacted with the Iowa Black RQ quencher, silencing fluorescence of the cyanine dye. After fabrication of the L-DNA-bead system, it was exposed to solutions with different $\mathrm{pH}$ values: pH 5.5 (50 mM Tris-acetate), 6.5 (50 mM MES), and $7.4(50 \mathrm{mM}$ Tris- $\mathrm{HCl})$ in a 100- $\mu \mathrm{L}$ final volume in a 96-well PCR plate. Melting curves were collected in the Cy5 channel using a ramp rate of $+0.02{ }^{\circ} \mathrm{C} / \mathrm{sec}$ from $30^{\circ} \mathrm{C}$ to $95^{\circ} \mathrm{C}$. Fluorescence measurements were performed at each step during the ramping process. Thermal and environment stability of the system was measured by a LightCycler 480 II Real-Time System provided by Roche Diagnostics and was analyzed using the LightCycler Adapt Software v1.1 from Roche Diagnostics. Cy5 fluorescence was measured with an excitation wavelength of $650 \mathrm{~nm}$ and an emission wavelength of $670 \mathrm{~nm}$.

\subsection{Melting Curve Measurements of L-DNA Sequences and Their Derivatives}

Thermal denaturation was measured by the 7500 Real Time PCR System from Applied Biosystems (Foster City, CA, USA) and analyzed using 7500 software V2.3. SYBR Green I from Molecular Probes (Eugene, OR, USA). SYBR Green I solution was diluted 20,000× and added to $600 \mathrm{ng}$ of DNA solution in a $100 \mu \mathrm{L}$ final volume in a 96-well PCR plate. Melting curves were measured in the SYBR channel using a ramp rate of $+0.5^{\circ} \mathrm{C} / \mathrm{min}$ from 30 to $95^{\circ} \mathrm{C}$. Fluorescence measurements were performed at each step during this ramping process. Melting curves were performed at least in triplicate.

\subsection{Evaluation of the Mole Fraction of Complementary Hybridization via UNAFold Software}

All single-stranded DNA sequences were saved in fasta file format. In a terminal command window, two single-stranded DNA files were opened. The molar concentrations of each sequence and the reaction salt concentrations were designated. In our analysis, $6 \mu \mathrm{M}$ DNA was tested. Yield from DNA hybridization was analyzed at sodium ion concentrations ranging from $50 \mathrm{mM}$ to $500 \mathrm{mM}$. After running the program, mole fractions of each component according to reaction temperature were obtained. Further details can be found in the protocol manual on the following website: http:/ / unafold.rna.albany.edu.

\subsection{Trend Line Drawing via CurveExpert Basic Software}

The graphs according to fluorescence data in figures (i.e., in Figure $5 b, c$ )were drawn by the CurveExpert program, which is based on the Weibull model among the sigmoidal functions. The equation of the Weibull model is written as below.

$$
y=a-b \times \exp \left(-c x^{d}\right)
$$

The $a$ is an integer, $b$ is $\frac{d}{\lambda}\left(\frac{x}{\lambda}\right)^{d-1}, c$ is $\left(-\frac{1}{\lambda}\right)^{d-1}, d$ expressed the order of events, and $\lambda$ is a number of frequencies. For detailed description and use of the program, please refer to the website: http: / / www.curveexpert.net.

\section{Results and Discussion}

To achieve multi-functionality in the molecular beacon system, a tree DNA-based nanostructure was used as a template [11,12]. Y-shaped DNA (Y-DNA) with three arms, 
each containing a different module, allows the body to have three different properties [13,14]. Multimodularity can be attained via a one-pot multistep organic synthesis [15]. As a test model for this study, we modified each arm of Y-DNA to have distinct functional modules and named the nanostructure looped DNA nanostructure (L-DNA). The modules on each arm are molecular beacons, consisting of a hairpin structure with Cy5 fluorophore and a dark quencher, biotin as a bead-sticker, and fluorescein phosphoarmidite (FAM) as a standard fluorescence (Figure 1). These functional modules in each arm allow for simultaneous detection of target molecules and fine-tuning of signal-off for target quantification. The original $Y$-DNA is composed of $Y_{1}, Y_{2}$, and $Y_{3}$ strands, and biotin, FAM, and molecular beacon are attached to the $5^{\prime}$-end of each strand respectively on L-DNA. The molecular beacon attached $Y_{3}$ strand is named as $Y_{L}$. The stability of L-shaped DNA can be affected by unexpected structural patterns caused by variations in the stem-loop internal structure. We therefore used the web-based software OligoAnalyzer 3.1 and Beacon Designer to design L-shaped DNA (Figure S1 of the online supplementary material). We focused on GC content, melting temperature $\left(\mathrm{T}_{\mathrm{m}}\right)$, and secondary structure to minimize the possibility of formation of secondary structures due to non-specific binding interactions between the L-DNA and the target sample.

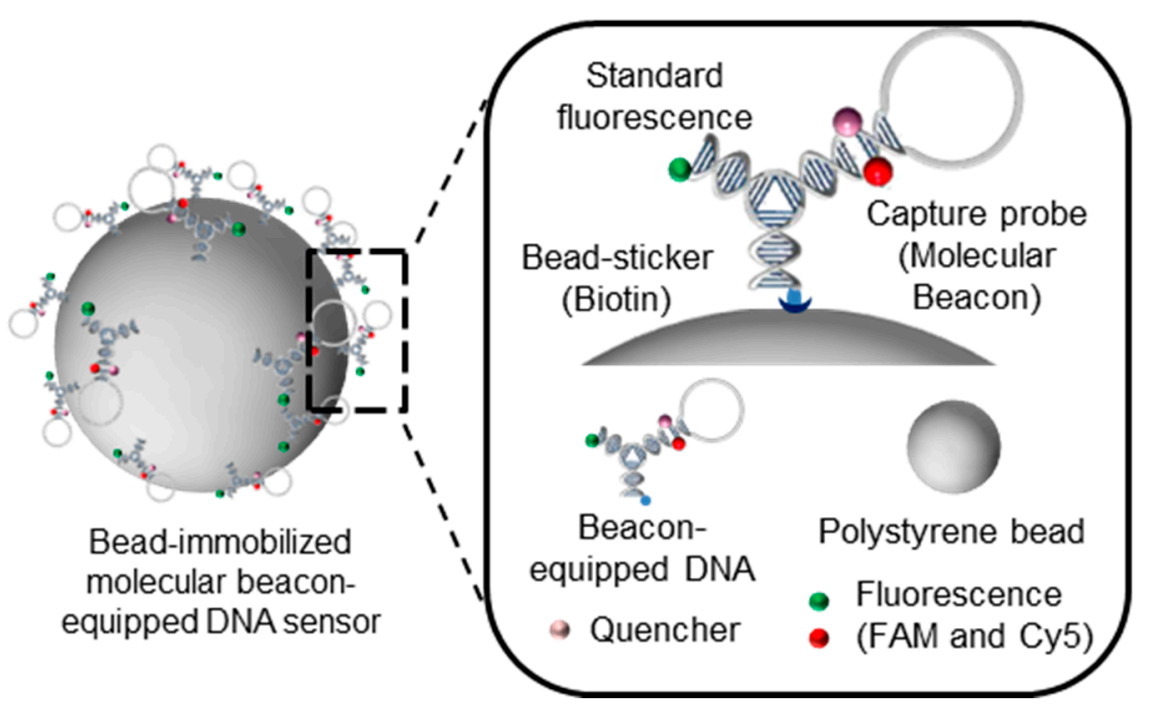

Figure 1. Schematic of the multimodular bead-immobilized molecular beacon-equipped DNA nanosensor. A looped DNA fragment that captures target RNA molecules was added onto a onecomponent single-stranded DNA molecule.

The efficiency of L-DNA can be altered by the formation of unexpected secondary structures. Therefore, it is important to optimize its structure in consideration of several environmental factors that affect thermodynamic stability (Figure S2). In particular, a more homogeneous complex can be obtained if possible secondary structures at different temperatures are evaluated. We investigated the thermal stability of L-DNA via both experimental and theoretical analyses of individual sequences (Figure 2 and Figure S3). Y-shaped DNA functionalized with one molecular beacon was assessed theoretically using the mfold program. The $T_{m}$ values of each oligonucleotide were measured by real-time PCR. In the temperature range from 37 to $50{ }^{\circ} \mathrm{C}$, both $Y_{1}$ and $Y_{2}$ were predicted to form non-secondary structures because of their length of 26 bases, whereas $Y_{L}$, which was 57 bases long and complementary to the target RNA sample, formed several different secondary structures. 
a

\begin{tabular}{c|cc|cc}
\hline \multicolumn{4}{c}{$Y_{\text {Loop }}$} \\
\hline & \multicolumn{2}{|c}{$37^{\circ} \mathrm{C}$} & \multicolumn{2}{c}{$50^{\circ} \mathrm{C}$} \\
& $\begin{array}{c}\Delta G \\
(\mathrm{kcal} / \mathrm{mol})\end{array}$ & $\mathrm{Tm}\left({ }^{\circ} \mathrm{C}\right)$ & $\begin{array}{c}\Delta \mathrm{G} \\
(\mathrm{kcal} / \mathrm{mol})\end{array}$ & $\mathrm{Tm}\left({ }^{\circ} \mathrm{C}\right)$ \\
\hline 1 & -2.78 & 52.30 & -0.42 & 52.30 \\
2 & -2.19 & 45.00 & -0.16 & 51.10 \\
3 & -2.09 & 48.50 & 0.10 & 48.30 \\
4 & -2.07 & 51.10 & 0.18 & 48.50 \\
5 & -2.07 & 46.60 & & \\
\hline
\end{tabular}

C

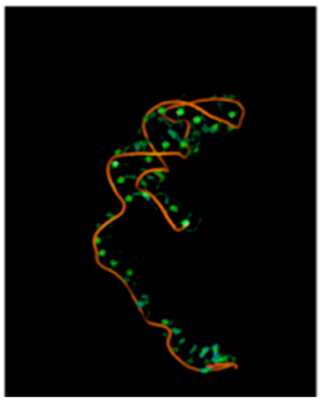

b
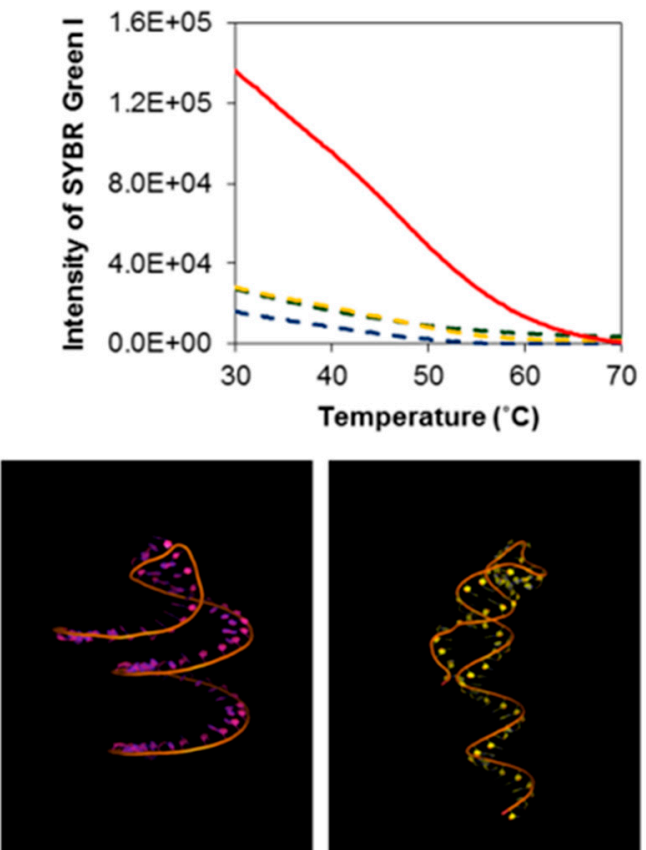

Figure 2. Empirical and theoretical analyses of possible secondary structures of L-DNA. (a) Theoretical analysis of the secondary structures of L-DNA via the Mfold program. $Y_{\mathrm{L}}$, which contains a loop-stem form, exhibited possible secondary structures with high thermodynamic stability at both $37^{\circ} \mathrm{C}$ and $50^{\circ} \mathrm{C}$. Both Gibbs free energy and $\mathrm{T}_{\mathrm{m}}$ values of its secondary structures are described in the table. (b) Melting curves of $Y_{1}$ (green), $Y_{2}$ (blue), $Y_{3}$ (orange), and $Y_{L}$ (red) as measured by RT-PCR. The graph indicates changes in fluorescence intensity of SYBR green I, which is specific to double-stranded DNAs. Data were obtained from triplicate experiments. (c) Three-dimensional topographic images of four different types of possible secondary structures of $\mathrm{Y}_{\mathrm{L}}$ at $50^{\circ} \mathrm{C}$.

This outcome was also confirmed experimentally. Interestingly, $\mathrm{Y}_{\mathrm{L}}$ alone showed stronger emission signals ( 4-fold) than the other $Y_{\mathrm{n}}$ at around $60^{\circ} \mathrm{C}$. No fluorescent emissions induced by detection were found from single components of the $Y_{n}$ samples. We studied this further using build-ups of single-stranded DNA fragments, including the complexes of $Y_{1}+Y_{2}, Y_{1}+Y_{L}, Y_{2}+Y_{L}$, and $Y_{1}+Y_{2}+Y_{L}$ (Figure S4). Most DNA constructs were synthesized below $60^{\circ} \mathrm{C}\left(\mathrm{T}_{\mathrm{m}}=56.5^{\circ} \mathrm{C}\right)$. Production efficiency was investigated by varying temperatures around $\mathrm{T}_{\mathrm{m}}$ (Figure $\mathrm{S} 4 \mathrm{~b}, \mathrm{c}$ ). Ideally, the binding fractions of oligo-fragments in each complex should be equal, and the total yield fraction should be 1.0. $Y_{L}+Y_{1}$ and $\mathrm{Y}_{\mathrm{L}}+\mathrm{Y}_{2}$ had molar yield fractions of 0.76 and 0.53 , respectively. The total proportion of unreacted fragments was $23.5 \%$ because the secondary structure of the longer $Y_{L}$ fragment could inhibit the hybridization of complexes. This result was confirmed by single-stranded conformational polymorphism (SSCP) analysis through a gel-electrophoretic migration shift assay (GEMSA) using a 15\% polyacrylamide gel (Figure 3) [16]. Staining of the gel with SYBR gold revealed that $Y_{L}$ had adopted a secondary structure conformation, and that the complete set of L-DNA complexes was fragmented [17,18]. Both $Y_{1}$ and $Y_{2}$ appeared as single bands (Figure 3a), but $Y_{L}$ was characterized by several bands, indicating potential secondary structures. After annealing, a set of DNA complexes involving $Y_{1}, Y_{2}, Y_{L}, Y_{1}$ $+Y_{2}, Y_{1}+Y_{L}$, and $Y_{2}+Y_{L}$ were represented by several bands, indicating the secondary structures of these complexes. $Y_{\mathrm{L}}$ was specifically labeled with fluorescein (FAM), and roughly $62.6 \%$ of $Y_{L}$-containing product was obtained (Figure $3 b, c$ ). This result confirms that $Y_{L}$ plays a significant role in product synthesis by competing with the formation of either secondary structures or products. To effectively recognize and capture a complementary RNA target, the loop structure of L-DNA was further examined (Figure 4). An open-close state of the loop on $\mathrm{Y}_{3}$ of L-DNA can be used for specific detection of an RNA target via fluorescence-resonance enhanced transfer (FRET), in which FRET signals are 
emitted as complementary RNA pairs with looped capture sequences (Figure 4). Working on-signaling may be strongly affected by environmental conditions such as target mass and reaction temperature. After L-DNA was synthesized, the $\mathrm{T}_{\mathrm{m}}$ of the loop-stem structure was different from the as-expected $\mathrm{T}_{\mathrm{m}}$ of $48^{\circ} \mathrm{C}$ (Figure $4 \mathrm{c}$ ); the $\mathrm{T}_{\mathrm{m}}$ was around $37{ }^{\circ} \mathrm{C}$, as determined by tracing the increase in the fluorescence of $\mathrm{Cy} 5$ as the fluorophore. In the case of the $\mathrm{Y}_{\mathrm{L}}$ sequence, the Cy5 signal increased at around $45^{\circ} \mathrm{C}$. In contrast, L-DNA and its byproducts such as $\mathrm{Y}_{\mathrm{L}}+\mathrm{Y}_{1}$ and $\mathrm{Y}_{\mathrm{L}}+\mathrm{Y}_{2}$ exhibited an increased Cy5 signal at $37{ }^{\circ} \mathrm{C}$, indicating that the loop-stem compartment was partially opened. This result implies that the loop-stem part of the L-DNA had a different thermal stability than $\mathrm{Y}_{\mathrm{L}}$ alone. It is speculated that the detection resolution of L-DNA could be interrupted. It is strongly recommended not to use the L-DNA at temperatures below $30^{\circ} \mathrm{C}$. We also investigated that the yield of L-DNA formation increased at high salt concentrations (Figure S5).

Prior to in vitro detection verification of the functionality of the synthesized L-DNAs, we examined the detection efficiency of L-DNA and its partial derivatives in solution. Signal increments of Cy5 for L-DNA and its derivatives $\left(Y_{L}+Y_{1}, Y_{L}+Y_{2}\right.$ and $\left.Y_{L}\right)$ were tested by varying the masses of EZH2 mRNA, which is a breast cancer-specific biomarker (Figure $4 \mathrm{~d}$ ) $[19,20]$. Following the optimized procedure, $5 \mu \mathrm{L}$ of EZH2 mRNA at concentrations of $0.12,0.6$, and $1.2 \mu \mathrm{M}$ were slowly mixed into $40 \mu \mathrm{L}$ of sample DNA nanostructures at $1.2 \mu \mathrm{M}$, after which the intensity of Cy5 was measured at $16{ }^{\circ} \mathrm{C}$. In Figure $4 \mathrm{c}$, as an example of disassembling the loop structure to characterize the on-signaling reaction, the loop structures in various combinations are thermally agitated. The alteration made in Cy5 intensity is much larger in case of L-DNA when compared to other combinations, which brings efficient on-signaling result from loop disassembly. As continued in Figure 4d, the favorable loop disassembly of L-DNA was then induced by the target EZH2 RNA, which resulted in better distinction between the signal from $0.12 \mu \mathrm{M}$ and $0.6 \mu \mathrm{M}$.

L-DNA was then applied for detection of cancer-specific microRNAs as a proof of concept for a potential cancer diagnosis platform, with internal fluorescent signals transmitted in situ. To test a miRNA model, miRNA21 was selected, and its complementary DNA sequence was incorporated into the L-DNA. Biotin-modified L-DNA was then conjugated onto streptavidin-coated polystyrene beads (PS beads) with a diameter of $110 \mathrm{~nm}$ via the avidin-biotin interaction (Figure 5 and Figure S7). Optimal parameters for the bead-immobilized L-DNAs were determined by varying conditions such as temperature and $\mathrm{pH}$ (Figure S8). The detection efficiencies of free L-DNA and bead-immobilized L-DNA were compared using FAM-tagged L-DNAs (sample preparation method described in the Supplementary Information). Fluorescence was monitored at different concentrations (2, $0.5,0.125,0.03125$, and $0 \mu \mathrm{M}$ ) of miRNAs (Figure $5 \mathrm{~b}, \mathrm{c}$ ). FAM was used as a standard, and the relative Cy5 signal/FAM fluorescence signal was obtained. The bead-immobilized L-DNA system could detect very low quantities of miRNA21 (as low as $0.03125 \mu \mathrm{M}$ ). Bead immobilization of L-DNA was possible up to 2000 units of L-DNA, leading to amplified fluorescence signals. The bead-immobilized system improved L-DNA detection efficacy in comparison to free L-DNA with regard to both sensitivity and specificity. However, as shown in Figure 5a, a large amount of L-DNA was lost during bead and L-DNA conjugation, so the total amount of L-DNA between the two control groups was different. Therefore, the fluorescence value did not increase after $0.5 \mu \mathrm{M}$ concentration, even if more miRNAs were given. 
a

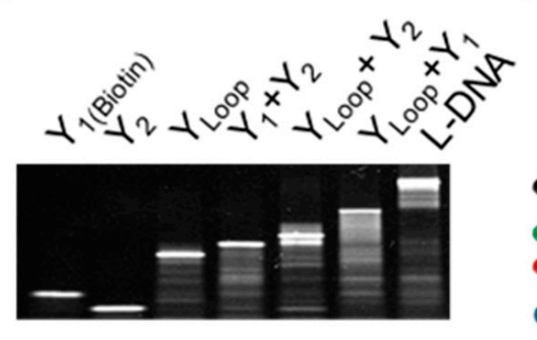

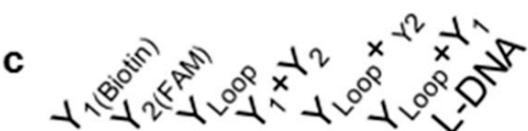

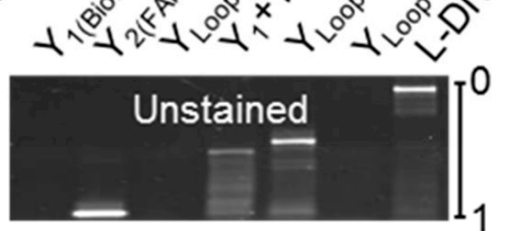

Stained with SYBR

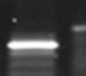

d

\begin{tabular}{|c|c|c|}
\hline Name & $\begin{array}{c}\text { Chemical } \\
\text { modification } \\
\text { at a } 5 \text { primed } \\
\text { end }\end{array}$ & Sequence \\
\hline$Y_{1 \text { (biotine) }}$ & 5' /Biotin/ & $\begin{array}{l}\text { TGGATCCGCATGA } \\
\text { CATTCGCCGTAAG }\end{array}$ \\
\hline$Y_{2(F A M)}$ & $5^{\prime} / \mathrm{FAM} /$ & $\begin{array}{l}\text { CTTACGGCGAATG } \\
\text { ACCGAATCAGCCT }\end{array}$ \\
\hline$Y_{\text {Loop }}$ & $\begin{array}{c}5^{\prime} / \text { Iowa Black } \\
\text { RQ/ } \\
\text { GCGAGGCCA } \\
\text { GACTGGGAA } \\
\text { GAAATCTGC } \\
\text { TCGC } \\
\text { /Cy5 } 5 \text { TM/ }\end{array}$ & $\begin{array}{l}\text { AGGCTGATTCGGT } \\
\text { TCATGCGGATCCA }\end{array}$ \\
\hline
\end{tabular}

b

- Quencher

- Fluorescence

(FAM\&Cy5)

- Biotin

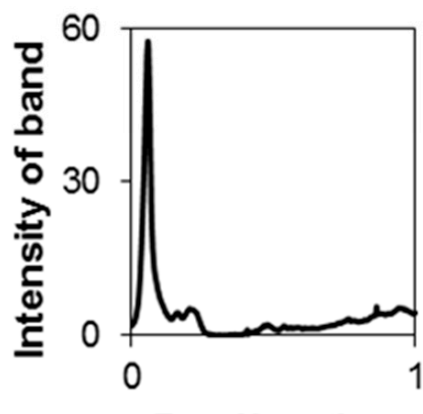

Band location

Figure 3. Evaluation of state-runs of L-DNA by single-strand conformation polymorphism (SSCP) analysis. (a) SSCP analysis of L-DNA and its partial constructs. Sequential build-ups of L-DNA were subjected to $15 \%$ polyacrylamide gel electrophoresis at $100 \mathrm{~V}$ for $2 \mathrm{~h}$, followed immediately by specific staining with $2 \mu \mathrm{g} / \mathrm{mL}$ SYBR gold for $30 \mathrm{~min}$. (b) Structural form of as-predicted L-DNA. (c) Gel electrophoretic image of a set of FAM-labeled L-DNAs. FAM-labeled single-stranded DNA fragments were present in all L-DNAs. After fluorescence intensity measurements, the yield of L-DNA was calculated using TotalLab Quant gel quantification software. Minimum profile was then used as a single background; the total yield of synthesized L-DNA was $62.6 \%$. (d) Sequence information for the fragments used in this experiment. 
a

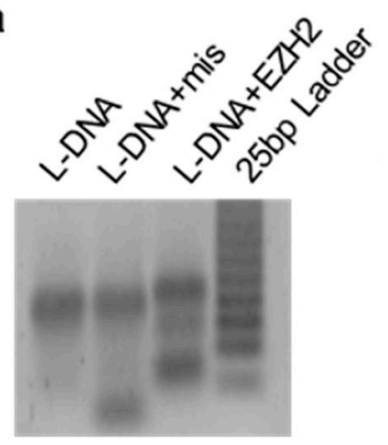

b

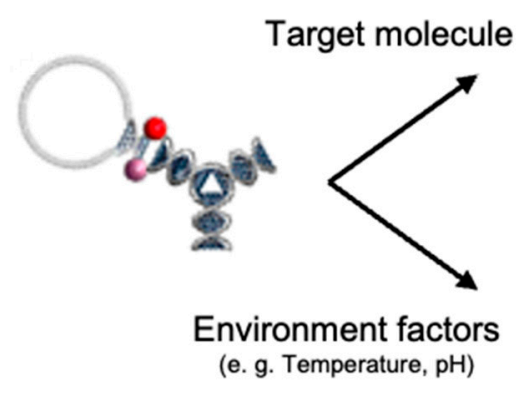

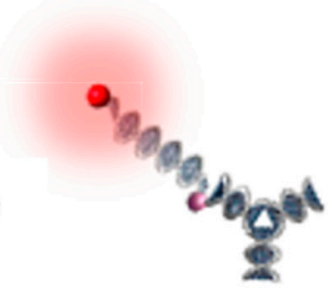

Detection of target molecule

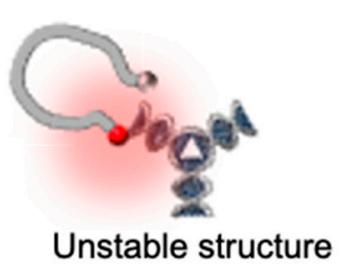

c

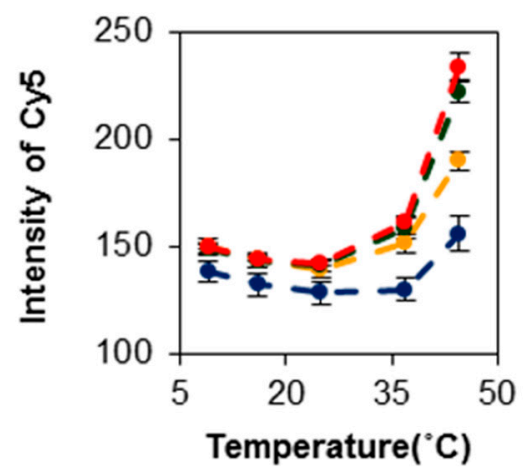

d

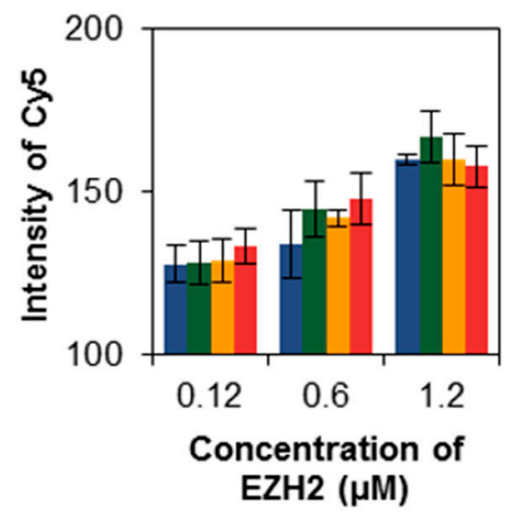

Figure 4. Evaluation of both thermodynamic stability and detection efficiency of L-DNA and its partial constructs. (a) Specific interaction between L-DNA and its complementary pair in a 3\% agarose gel. The same amounts $(6 \mu \mathrm{M})$ of mismatched oligonucleotide (mis, 5' - CAT ATG GGC TCC ATC GGC GCA-3') and fully matched oligonucleotide (5'-CAG ATT TCT TCC CAG TCT GGC-3') were used for comparison. (b) Schematic of the detection mechanism of L-DNA in solution. L-DNAs formed a looped structure in molecular beacon target capture. After target binding, the beacon adopted an open state, emitting a strong Cy5 signal. Environmental factors such as temperature and pH can destabilize the loop-stem structure and can affect the fluorescence signal. (c) Cy5 signal of L-DNA (red), $Y_{L}+Y_{1}$ (orange), $Y_{L}+Y_{2}$ (green), and $Y_{L}$ (blue) at different temperatures $\left(9,16,25,37\right.$, and $\left.45^{\circ} \mathrm{C}\right)$. (d) Cy5 signal variations of L-DNA at different target concentrations at $16^{\circ} \mathrm{C}$. In both (c) and (d), the fluorescent intensities of $\mathrm{Cy} 5$ measured by spectrophotometric analysis were obtained from triplicate experiments. 
a
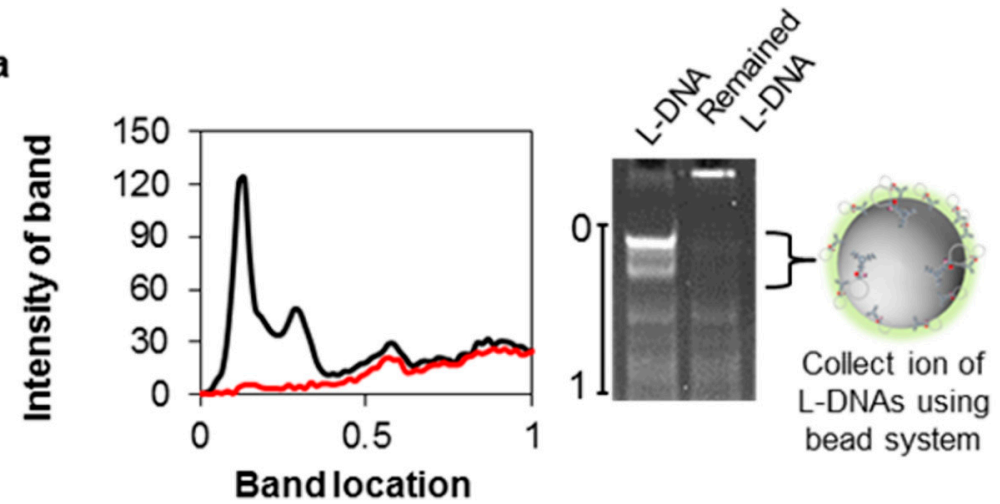

b
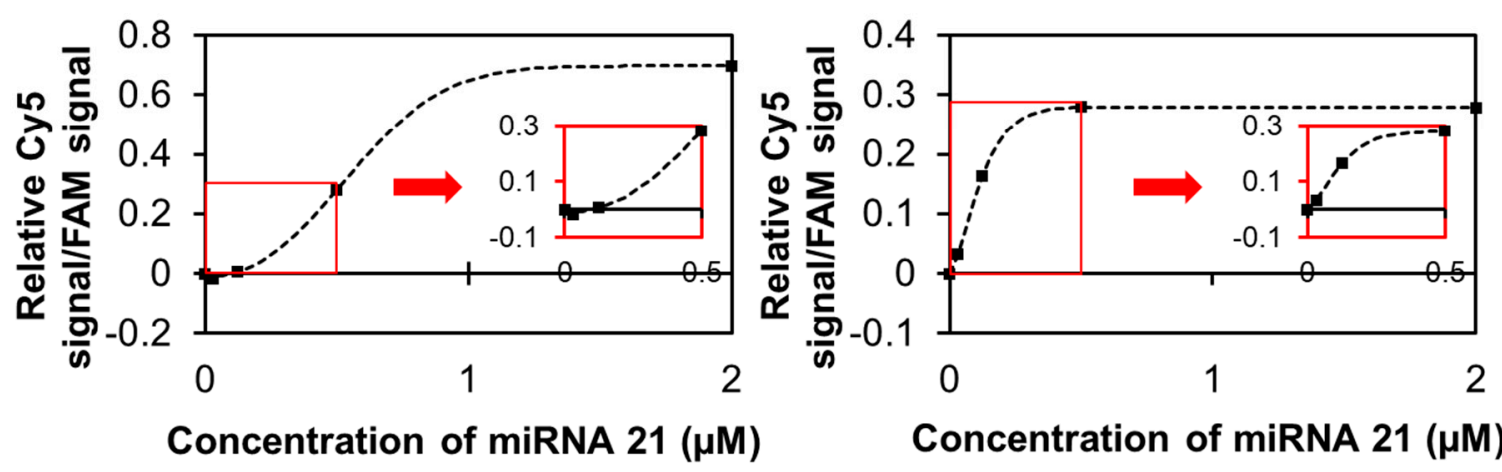

Concentration of miRNA $21(\mu \mathrm{M})$

Figure 5. Construction of a bead-immobilized molecular beacon-equipped DNA nanosensor and its detection efficiency. (a) 15\% PAGE image of the molecular-beacon-equipped DNA nanosensor (L-DNA) and the rest of L-DNAs. L-DNA was collected by $110 \mathrm{~nm}$-sized PS beads via avidin-biotin conjugate chemistry. Red and black lines indicate L-DNAs and remaining L-DNAs, respectively. Minimum profile was used as a background signal; the purity of L-DNA increased from 58.4 to $86.8 \%$ when a solid support was used. (b) Detection efficiencies of free L-DNA and (c) the bead-immobilized L-DNA nanosensor system were compared. All data collected were obtained from triplicate experiments. The miRNA 21 was used at concentrations of $2,0.5,0.125,0.03125$, and used $0 \mu \mathrm{M}$ as a negative control.

\section{Conclusions}

In conclusion, we described a DNA nanostructure-based miRNA detector under consideration of thermodynamical stability of the nanostructure and probe for maximized interaction between probe and target, signal adjustment, and immobilization. Thermodynamic stability of DNA nanostructure scaffolded probe was analyzed and optimized empirically and theoretically. Diagnostic utility of an optimized DNA nanostructure was explored for detection of small quantities of a breast-cancer-specific RNA marker; our detection system was 16-fold more sensitive than conventional systems. We are currently adapting this diagnostic platform for detection of other genetic variants associated with diseases.

Supplementary Materials: The following are available online at https:/ /www.mdpi.com/article/10 $.3390 /$ nano11061617/s1, Figure S1: theoretical evaluation regarding the design of loop sequence $\left(\mathrm{Y}_{\mathrm{L}}\right)$, a single-stranded oligo-fragment on a molecular beacon-equipped DNA nanobiosensor, Figure S2: algorithm diagram for optimized parameters for the synthesis of a bead-free nanobiosensor, Figure S3: sequence information for template DNA and bead-free nanobiosensor or L-DNA, Figure S4: melting curve analysis of DNA derivatives, Figure S5: yield increment in L-DNA according to salt concentrations, Figure S6: detection efficiencies of L-DNA and its derivatives, Figure S7: synthesis of a bead-immobilized molecular beacon-equipped DNA nanobiosensor system and confirmation of unreacted sequences, Figure S8: environmental stability of bead-immobilized nanobiosensor system, and Supplementary references. 
Author Contributions: The manuscript was written through contributions of all authors. All authors have read and agreed to the published version of the manuscript.

Funding: The study was funded by a grant from the Basic Science Research Program through the National Research Foundation of Korea funded by the Ministry of Science, ICT, and Future Planning (Grant no. 2019R1 A2 C2002390).

Institutional Review Board Statement: Not applicable.

Informed Consent Statement: Not applicable.

Data Availability Statement: Not applicable.

Acknowledgments: This work is partially funded by a grant from the Basic Science Research Program through the National Research Foundation of Korea funded by the Ministry of Science, ICT, and Future Planning (Grant no. 2019R1 A2 C2002390). We thank the SKKU Research facilities for measurements. We also acknowledge Mr. In Hyun Song and Ms. Woo Jung Shin for their contribution to this works.

Conflicts of Interest: The authors declare no conflict of interest.

Table of Contents Graphic: The bead-immobilized multimodular molecular beacon-equipped DNA nanobiosensor is established; Immobilization of this detector amplified fluorescence signals substantially with selectivity when specific target RNA was captured, and these signals are simultaneously normalized by standard fluorescence.

\section{References}

1. Wodicka, L.; Dong, H.; Mittmann, M.; Ho, M.-H.; Lockhart, D.J. Genome-wide expression monitoring in Saccharomyces cerevisiae. Nat. Biotechnol. 1997, 15, 1359-1367. [CrossRef] [PubMed]

2. Iyer, V.R.; Eisen, M.B.; Ross, D.T.; Schuler, G.; Moore, T.; Lee, J.C.F.; Trent, J.M.; Staudt, L.M., Jr.; Hudson, J.; Boguski, M.S.; et al. The transcriptional program in the response of human fibroblasts to serum. Science 1999, 283, 83-87. [CrossRef] [PubMed]

3. Emily, K.; Ryan, F.; Egan, H.D.; Yi, H.N.; Richard, A.; Rosanne, M.G.; Beatriz, P.S.; Paul, S.F.; Megan, D.; David, J.H.; et al. Amplification-free electrochemiluminescence molecular beacon-based microRNA sensing using a mobile phone for detection. Sens. Actuators B Chem. 2020, 330, 129621.

4. Yinhua, H.; Xiuping, C.; Yingshu, G.; Xiaofei, Z.; Dongjiao, L.; Si-Kai, C.; Guang, C.; Jinmao, Y. An aggregation-induced emission fluorogen/DNA probe carrying an endosome escaping pass for tracking reduced thiol compounds in cells. Anal. Bioanal. Chem. 2020, 412, 7811-7817.

5. Bidar, N.; Amini, M.; Oroojalian, F.; Baradaran, B.; Hosseini, S.S.; Shahbazi, M.A.; Hashemzaei, M.; Mokhtarzadeh, A.; Hamblin, M.R.; de la Guardia, M. Molecular beacon strategies for sensing purpose. Trends Analyt Chem. 2020, 134, 116143.

6. Bingzhi, L.; Anqi, X.; Siying, X.; Lei, L.; Zhirun, J.; Tiying, S.; Xing, Z.; He, H. Signal-Amplified Detection of the Tumor Biomarker FEN1 Based on Cleavage-Induced Ligation of a Dumbbell DNA Probe and Rolling Circle Amplification. Anal. Chem. 2021, 93, 3287-3294.

7. Negar, B.; Fatemeh, O.; Behzad, B.; Shirin, E.; Mohammad, A.; Asiyeh, J.; Seyed, S.H.; Paria, P.P.; Ahad, M.; la Miguelde, G. Monitoring of microRNA using molecular beacons approaches: Recent advances. Trends Analyt Chem. 2020, $131,116021$.

8. Peng, L.; Tan, W. Thermodynamic and Kinetic Properties of Molecular Beacons. In Molecular Beacons, 1st ed.; Yang, C.J., Tan, W., Eds.; Springer: Berlin/Heidelberg, Germany, 2013; pp. 19-43.

9. Wang, H.; Li, J.; Liu, H.; Liu, Q.; Mei, Q.; Wang, Y.; Zhu, J.; He, N.; Lu, Z. Label-free hybridization detection of a single nucleotide mismatch by immobilization of molecular beacons on an agarose film. Nucl. Acids Res. 2002, 30, e61. [CrossRef] [PubMed]

10. Pei, H.; Zuo, X.; Pan, D.; Shi, J.; Huang, Q.; Fan, C. Scaffolded biosensors with designed DNA nanostructures. NPG Asia Mater. 2013, 5, e51. [CrossRef]

11. Seeman, N.C. De novo design of sequences for nucleic acid structural engineering. J. Biomol. Struc. Dyn. 1990, 8, 573-581. [CrossRef] [PubMed]

12. Wang, X.; Seeman, N.C. Assembly and characterization of 8-arm and 12-arm DNA branched junctions. J. Am. Chem. Soc. 2007, 129, 8169-8176. [CrossRef] [PubMed]

13. Lee, J.; Roh, Y.H.; Um, S.H.; Funabashi, H.; Cheng, W.; Cha, J.J.; Kiatwuthinon, P.; Muller, D.A.; Luo, D. Multifunctional nanoarchitectures from DNA-based ABC monomers. Nat. Nanotechnol. 2009, 4, 430-436. [CrossRef] [PubMed]

14. Benvin, A.L.; Creeger, Y.; Fisher, G.W.; Ballou, B.A.; Waggoner, S.; Armitage, B.A. Fluorescent DNA nanotags: Supramolecular fluorescent labels based on intercalating dye arrays assembled on nanostructured DNA templates. J. Am. Chem. Soc. 2007, 129, 2025-2034. [CrossRef] [PubMed]

15. McKee, M.L.; Milnes, P.J.; Bath, J.; Stulz, E.; O'Reilly, R.K.; Turberfield, A.J. Programmable One-Pot Multistep Organic Synthesis Using DNA Junctions. J. Am. Chem. Soc. 2012, 134, 1446-1449. [CrossRef] [PubMed] 
16. Um, S.H.; Lee, J.B.; Kwon, S.Y.; Li, Y.; Luo, D. Dendrimer-like DNA-based fluorescence nanobarcodes. Nat. Prot. $2006,1,995$. [CrossRef] [PubMed]

17. Gasser, R.B.; Hu, M.; Chilton, N.B.; Campbell, B.E.; Jex, A.J.; Otranto, D.; Cafarchia, C.; Beveridge, I.; Zhu, X. Single-strand conformation polymorphism (SSCP) for the analysis of genetic variation. Nat. Prot. 2006, 1, 3121-3128. [CrossRef] [PubMed]

18. Biyani, M.; Nishigaki, K. Single-strand conformation polymorphism (SSCP) of oligodeoxyribonucleotides: An insight into solution structural dynamics of DNAs provided by gel electrophoresis and molecular dynamics simulations. J. Biochem. 2005, 138, 363-373. [CrossRef]

19. Kleer, C.G.; Cao, Q.; Varambally, S.; Shen, R.; Ota, I.; Tomlins, S.A.; Ghosh, D.; Sewalt, R.G.; Otte, A.P.; Hayes, D.F.; et al. EZH2 is a marker of aggressive breast cancer and promotes neoplastic transformation of breast epithelial cells. Proc. Natl. Acad. Sci. USA 2003, 100, 11606-11611. [CrossRef]

20. Gong, Y.; Huo, L.; Liu, P.; Sneige, N.; Sun, X.; Ueno, N.; Lucci, T.A.; Buchholz, T.A.; Valero, V.; Cristofanilli, M. Polycomb group protein EZH2 is frequently expressed in inflammatory breast cancer and is predictive of worse clinical outcome. Cancer 2011, 117, 5476-5484. [CrossRef] [PubMed] 